\title{
Teaching NeuroImages: Frontal lobe involvement in adult-onset cerebral X-linked adrenoleukodystrophy
}

Chenchen Liu, MD, * Yayun Cao, MD, * and Bitao Bu, MD

Neurology ${ }^{\circledR}$ 2019;93:e1326-e1327. doi:10.1212/WNL.0000000000008181

A 42-year-old man presented with 1 year of progressive behavioral and personality changes. His antenatal, birth, and neurodevelopment were unremarkable. Examination showed hyperactive behavior, lower limbs paralysis (Medical Research Council grading 3) with pyramidal signs, and no skin hyperpigmentation or visual disturbance. Brain MRI revealed diffuse lesions in both frontal lobes, with peripheral rim restricted diffusion and enhancement (figure 1). Elevated plasma very-longchain fatty acid level, p.Ser98Ter mutation in ABCD1 gene, and his pedigree (figure 2) confirmed

Figure 1 Brain MRI
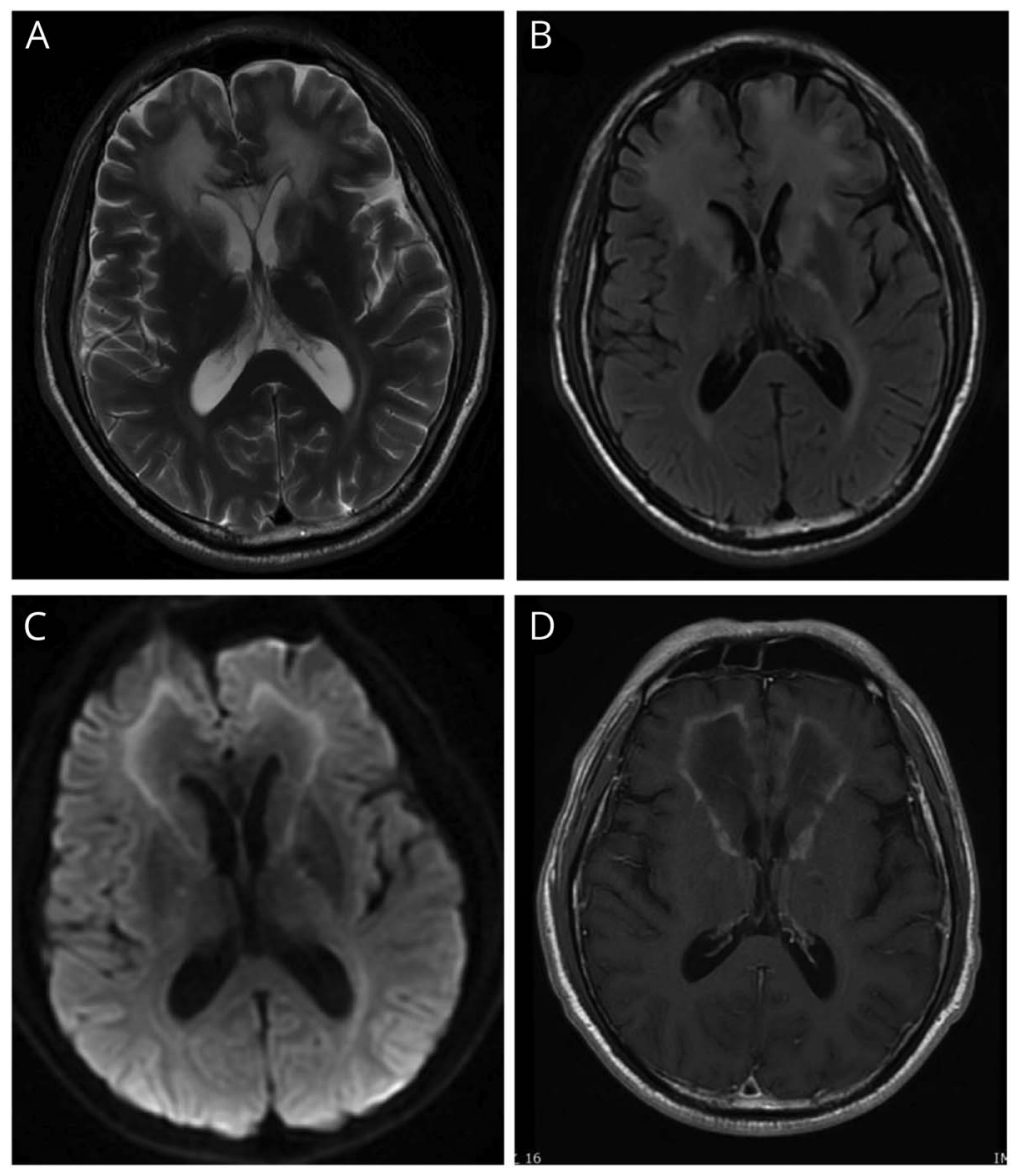

Axial T2-weighted (A) and fluid-attenuated inversion recovery (B) images show diffuse white matter hyperintensity in both frontal lobes. Diffusion-weighted imaging sequence reveals peripheral rim restricted diffusion in the white matter of the frontal lobes (C), with enhancement (D).

\section{Correspondence}

Dr. Bu

bubitao@yeah.net

\section{MORE ONLINE}

\section{$\rightarrow$ Teaching slides}

links.lww.com/WNL/

A960

*These authors contributed equally to this work.

From the Department of Neurology, Tongji Hospital, Tongji Medical College, Huazhong University of Science and Technology, Wuhan, China.

Go to Neurology.org/N for full disclosures. Funding information and disclosures deemed relevant by the authors, if any, are provided at the end of the article. 


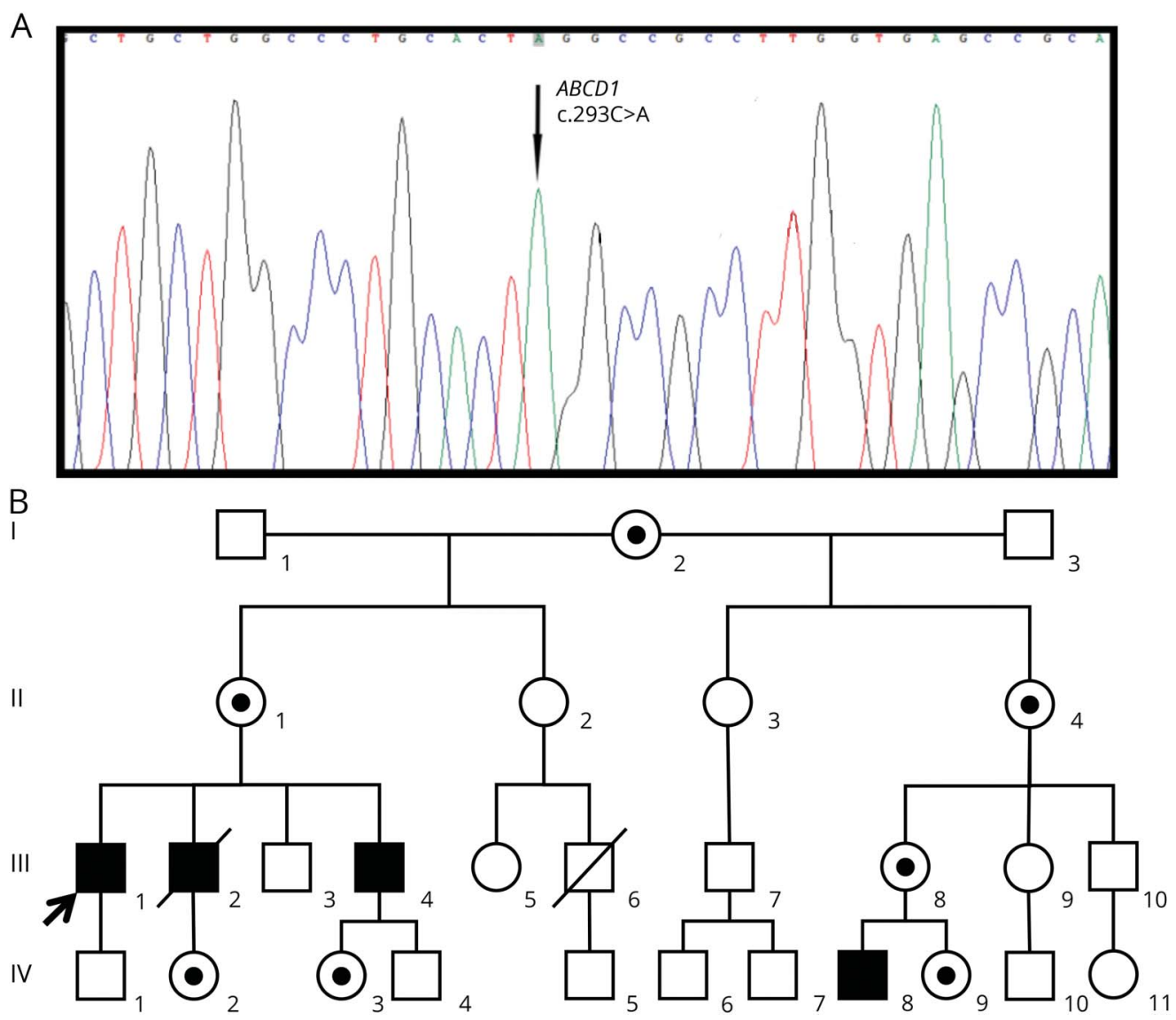

(A) Sequence determination of c.293C>A (p.Ser98Ter) mutation of the $A B C D 1$ gene. The arrow indicates the involved nucleotide. (B) Family tree: The presented case is marked with an arrow. III-2, III-4, and IV-8 had X-linked adrenoleukodystrophy; I-2, II-1, II-4, III-8, IV-2, IV-3, and IV-9 were female carriers.

the diagnosis of adult-onset cerebral X-linked adrenoleukodystrophy (X-ALD). X-ALD is an inborn error of metabolism predominantly within posterior involvement including parietooccipital lobes and splenium of the corpus callosum; about $15 \%$ of patients have an anterior pattern of atypical involvement. ${ }^{1,2}$ Frontal involvement can be seen in X-ALD, and this imaging feature can expedite the diagnosis of this atypical X-ALD.

\section{Study funding}

No targeted funding reported.

\section{Disclosure}

The authors report no disclosures relevant to the manuscript. Go to Neurology.org/N for full disclosures.

Appendix Authors

\begin{tabular}{|c|c|c|c|}
\hline Name & Location & Role & Contribution \\
\hline $\begin{array}{l}\text { Chenchen } \\
\text { Liu, MD }\end{array}$ & $\begin{array}{l}\text { Tongji Hospital, Tongji } \\
\text { Medical College, } \\
\text { Huazhong University } \\
\text { of Science and } \\
\text { Technology }\end{array}$ & Author & $\begin{array}{l}\text { Study concept and } \\
\text { design, acquisition of } \\
\text { data, analysis and } \\
\text { interpretation of data }\end{array}$ \\
\hline
\end{tabular}

Appendix (continued)

\begin{tabular}{llll}
\hline Name & Location & Role & Contribution \\
\hline $\begin{array}{l}\text { Yayun } \\
\text { Cao, MD }\end{array}$ & $\begin{array}{l}\text { Tongji Hospital, } \\
\text { Tongji Medical } \\
\text { College, Huazhong } \\
\text { University of } \\
\text { Science and }\end{array}$ & Author & $\begin{array}{l}\text { Study concept and } \\
\text { design, acquisition of } \\
\text { data, analysis and } \\
\text { interpretation of data }\end{array}$ \\
& Technology & \\
\hline Bitao Bu, & Tongji Hospital, & Author & Study concept and \\
MD & Tongji Medical & & $\begin{array}{l}\text { design, critical revision } \\
\text { of manuscript for } \\
\text { intellectual content }\end{array}$ \\
& $\begin{array}{l}\text { College, Huazhong } \\
\text { University of }\end{array}$ & & \\
& Science and & & \\
& Technology & & \\
\hline
\end{tabular}

\section{References}

1. Moser HW, Loes DJ, Melhem ER, et al. X-linked adrenoleukodystrophy: overview and prognosis as a function of age and brain magnetic resonance imaging abnormality: a study involving 372 patients. Neuropediatrics 2000;31: $227-239$.

2. Loes DJ, Fatemi A, Melhem ER, et al. Analysis of MRI patterns aids prediction of progression in X-linked adrenoleukodystrophy. Neurology 2003;61: 369-374. 


\section{Neurology}

\section{Teaching NeuroImages: Frontal lobe involvement in adult-onset cerebral $\mathrm{X}$-linked adrenoleukodystrophy}

Chenchen Liu, Yayun Cao and Bitao Bu

Neurology 2019;93;e1326-e1327

DOI 10.1212/WNL.0000000000008181

This information is current as of September 24, 2019

\section{Updated Information \&} Services

References

Subspecialty Collections

Permissions \& Licensing

Reprints including high resolution figures, can be found at: http://n.neurology.org/content/93/13/e1326.full

This article cites 2 articles, 1 of which you can access for free at: http://n.neurology.org/content/93/13/e1326.full\#ref-list-1

This article, along with others on similar topics, appears in the following collection(s):

\section{All Genetics}

http://n.neurology.org/cgi/collection/all_genetics

Information about reproducing this article in parts (figures,tables) or in its entirety can be found online at:

http://www.neurology.org/about/about_the_journal\#permissions

Information about ordering reprints can be found online:

http://n.neurology.org/subscribers/advertise

Neurology ${ }^{\circledR}$ is the official journal of the American Academy of Neurology. Published continuously since 1951, it is now a weekly with 48 issues per year. Copyright @ 2019 American Academy of Neurology. All rights reserved. Print ISSN: 0028-3878. Online ISSN: 1526-632X.

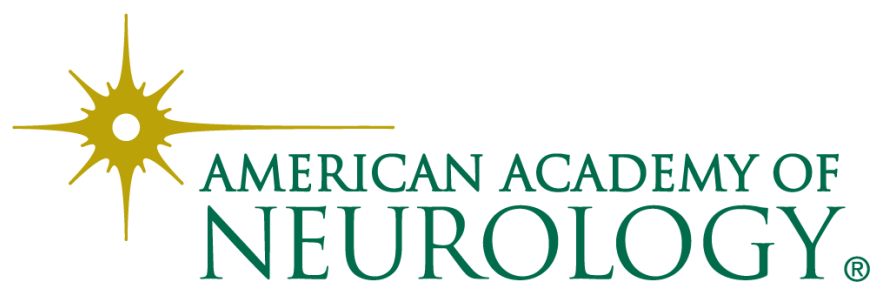

